\title{
THERAPEUTIC MANAGEMENT OF CLINICAL MASTITIS IN A MURRAH
}

\section{BUFFALO: A CASE REPORT}

\section{T. GEETHA ${ }^{1}$ \& P. TENSINGH GNANARAJ ${ }^{2}$}

${ }^{1}$ Assistant Professor, Instructional Livestock Farm complex, Madhavaram Milk Colony, Chennai, Tamil Nadu, India

${ }^{2}$ Professor and Head, Instructional Livestock Farm complex, Madhavaram Milk Colony, Chennai, Tamil Nadu, India

ABSTRACT
Mastitis is one of the most financially significant deadly diseases of milking animals and causes the glandular
tissues' changes affecting the quantity and the quality of the milk. The frequency of clinical mastitis in buffalo ranges
between 8 to $40 \%$. According to the reports of Moroni et al. (2006), the quarter-wise occurrence of intermammary
infection in buffaloes was $66 \%$. Since the mammary gland is highly susceptible to infection during the periparturient
period, the incidence was highest during the 30 days after calving. The current study deals with the acute clinical mastitis
treatment in a Murrah buffalo.
KEYWORDS: Clinical Mastitis, Periparturient Period \& Murrah Buffalo

Received: Apr 30, 2018; Accepted: May 20, 2018; Published: Dec 05, 2018; Paper Id.: IJASRDEC201812

\section{INTRODUCTION}

\section{Case History and Observations}

A 6-year-old Murrah buffalo yielding 10 litres milk/day and weighing $350 \mathrm{~kg}$ approximately during her second lactation, was observed with a history of a sudden start of anorexia, reduced liquid intake, a sudden drop in yield of milk and severe painful swelling of the udder at Dairy unit of TANUVAS, ILFC, Madhavaram milk colony, Chennai. All quarters of the animal had been observed to be normal in the evening during milking as stated by the Milker of Dairy unit, but in the morning of the next day, the udder was severely swollen, and the animal couldn't walk. On clinical examination, the animal showed tachycardia $(89 / \mathrm{min})$, pyrexia $\left(103.0^{\circ} \mathrm{F}\right)$, and tachypoenia (32/min). On physical examination of the udder (especially the right hind (RH) quarter), it was found to be painful, hot, and highly inflammed, and it was cracked on the swollen quarter. According to Sreedevi et al. (2002), in more than $80 \%$ of cases, the illness is limited to a single quarter and both quarters involvement may be observed in very much lower percentage of cases, and there will be abnormal enlargement of udder and teats with gradual sloughing of the teats. The milk from the affected quarters was like custard, yellow in coloration and with clots or flet a. These observations were in accordance to the finding of Peidy Sreeramulu (1993). With 70\% ethyl alcohol, proper disinfection of teat surface is done and a milk sample of $30 \mathrm{ml}$ from each quarter like left hind $(\mathrm{LH})$, left fore (LF), right fore (RF) and right hind (RH) was collected in sterile vials after spurting few streams aseptically, and processed within one hour of collection. As per Devi et al., (1997), the modified California Mastitis Test (MCMT) was performed immediately and exposed that the milk sample from the RH quarter was ' + ++ 'positive followed by LH (+) to MCMT and both the forequarters were negative to MCMT. By the method of Schalm et al. (1971), the microscopic examination of milk for Somatic Cell Count (SCC) revealed that the maximum number of cells $\left(29 \times 10^{5}\right.$ cells $\left./ \mathrm{ml}\right)$ are present in the RH quarter followed by the LH quarter $\left(2.6\right.$ X $10^{5}$ 
cells $/ \mathrm{ml})$. The SCC of the RF and the LF quarters was under normal range $\left(0.81 \times 10^{5} \mathrm{cells} / \mathrm{ml}\right.$ and $0.59 \times 10^{5} \mathrm{cells} / \mathrm{ml}$ respectively), for identification and isolation of bacteria (Cruickshank et al., 1975). Standard bacteriological procedures were accepted, and E. Coli and Staphylococcus aureus were used as the etiological agents. The bacterial isolates were exposed to an in-vitro antibiotic sensitivity test after identification and isolation by the disc diffusion method (Bauer $e t$ al., 1966). The antibiotic sensitivity pattern displayed that the isolated organisms were highly sensitive to ciprofloxacin $(+++$ + ), enrofloxacin $(++++)$, followed by gentamicin $(+++)$ and oxytetracycline $(+++)$. Swati Sahay (2000), Sharma (2000) and Prasad (2001), also presented maximum sensitivity to enrofloxacin in cases of mastitis. Against the isolated organisms, penicillin was ineffective completely. Based on the signs, clinical examination and diagnostic tests, the case was identified as acute clinical mastitis.

\section{RESULTS AND DISCUSSIONS}

For 5 days, the buffalo was treated with Inj. Enrofloxacin -15 ml I/M per day. For 3 days, Inj. Chlorpheniramine maleate $-7 \mathrm{ml}$ and Inj. Meloxicam $-15 \mathrm{ml}$ was given, intramuscularly. As a supportive therapy, inj. DNS - 15, I/V was given for 3 days and Agrimin forte-mineral mixture @ $30 \mathrm{~g}$ per day. The milker was also guided to make complete recurrent milking for every 4-5 hours. The animal showed development from the second day of treatment, and on the fifth day, it was recovered completely with the disappearance of clinical signs completely. The milk was clear, free from flwas or clots and seen to be white in colour. From all the quarters, the milk samples were found negative to SCC, MCMT and cultural test.

Mastitis was instigated by multietiolgical agents, but the major pathogens are Staphylococcus aureus and E. coli of bovine mastitis. Staphylococcus aureus is a usual resident of the udder and E. coli is commonly found in the environment of the animals. Therefore, when these microorganisms get the chance during injury or trauma to udder, unhygienic condition and improper milking technique, they enter the teat canal and mastitis grows. The signs of tachycardia, pyrexia, depression, severe inflammatory swelling of udder, loss of milk yield indicated acute type of mastitis. Chakarbarti (2000) reported similar signs in mastitis. To check the multiplication of bacteria and septicaemia, the antibiotic enrofloxacin helps. After intramuscular administration, the high cure rate by enrofloxacin may be due to the high tissue concentration exceeding MIC values and high bio-availability for most pathogens (Gatne et al., 1997). Chlorpheniramine maleate was used to neutralize histamine release and Meloxicam as anti-inflammatory agent. DNS helps in diluting the concentration of toxins produced by organisms and used as a supportive therapy. The owner was also recommended to provide mineral mixture supplementation because some trace minerals improve the mammary (cellular) defence mechanism. Hence, enrofloxacin administration along with supportive therapy assisted in the quick recovery of this clinical case of mastitis after confirmation, in the present study.

\section{CONCLUSIONS}

From The Study It Is Concluded That The Mcmt Can Be Used To Diagnose The Mastitis Clinically At Herd Level And The Abst Can Be Used To Identify The Appropriate Antibiotic For Effective Treatment Of Mastitis. In The Present Study The Abst Revealed Highly Sensitive For Enrofloxacin And Hence It Was Administered The Animal Had Uneventful Recover. 


\section{REFERENCES}

1. Bauer, A. W., W. M. M. Kieby., J. C. Shrenis and M. Turck. 1966. Antibiotic susceptibity testing by a standardized single disc diffusion method. Am. J. Clin. Pathol., 45: 453-496.

2. Chakarbarti, A. 2000. A Textbook of Preventine Veterinary Medicine. Kalyani Publishers, Delhi.

3. Cruickshank, R., J. P. Duguid., H. P. Harmion. and B. P. Swain. 1975. Medical microbiology, Vol. 2,12 ${ }^{\text {th }}$ ed. Churchill Livingstone, Edinburgh, London and NewYork.

4. Devi, B. K., P. C. Shukla. and R. K. Bagherwal. 1997. Incidence of sub clinical mastitis in cows. Indian J. Dairy Sci., 50(6): 477-478.

5. Gatne, M. M., A. P. Somkumar, P. K. Hendre and V. V. Ranade. 1997. The blue cross book, 8:24-25.

6. Moroni, P., Sgoifo, C., Pisoni, G., Bronzo, V., Castiglioni, B., and Boettcher, P. J. 2006. Relationships between somatic cell count and intramammary infection in buffaloes. J. Dairy Sci., 89(3): 998-1003.

7. Pathak, N. N. and Sharma, M. C. 1988. Buffalo health management. In A compendium of latest research information based on Indian studies. ICAR, New Delhi, pp. 160-161.

8. Kareem, K. A., \& Ali, W. D. A. In-Vitro Evaluation Of Antibacterial Activity Of Silybum Marianum Seeds Oil, Ethanolic Extract And Antibiotics Against Isolated Bacteria.

9. Peidy Sreeramulu. 1993. Indian Vet. J., 70: 1174-1176.

10. Prasad, B. 2001. IAAVR Proceeding the Round Table Conference on Mastitis. 22-23 Feb., 2001, Luthiana,. pp. 44-50.

11. Schalm, O. W., Carrol, E. J. and Jain, N. C. 1971. Bovine Mastitis. Lea and Febiger, Philadelphia, U. S. A.

12. Shanna, A. K. 2000. M. V. Sc. Thesis submitted to H. P. K. V., Palampur, Himachal Pradesh, India.

13. Sreedevi, B., Malleshwar Rao, U. V. N. and Venkat Reddy, T. 2002. Proceeding of the IAAVR, Round Table Conference on Mastitis, No.3: 33-35.

14. Swati Sahay. 2000. M. V. Sc. Thesis submitted to R. A. U., Pusa, Samastipur, Bihar, India. 
